\title{
Penile fracture
}

\author{
Anurag Chahal, ${ }^{1}$ Sahil Gupta, ${ }^{2}$ Chandan Das ${ }^{1}$
}

${ }^{1}$ Department of

Radiodiagnosis, All India Institute of Medical Sciences, New Delhi, India

${ }^{2}$ Department of Surgical Disciplines, All India Institute of Medical Sciences, New Delhi, India

\section{Correspondence to}

Dr Sahil Gupta, sahil.self@gmail.com

Accepted 1 May 2016

\section{DESCRIPTION}

A 32-year-old man presented to our emergency department, with pain, swelling and a dorsal curvature in his penis. He had severe pain and lost tumescence with a snapping sound during vigorous sexual intercourse. On examination, he had a swelling with ecchymosis on the ventral aspect of his penis causing an acute dorsal angulation (figure 1). There was no blood at the meatus/haematuria. Taking the typical history and examination findings into account, the diagnosis of penile fracture was made. Ultrasound showed a focal tear in the medial wall of the right corpora cavernosa with haematoma tracking ventrally and displacing the corpora spongiosa to the other side (figures 2 and 3).

The patient was taken for emergent haematoma evacuation and corporal repair.

Penile fracture occurs when an erect penis undergoes a blunt trauma during sexual intercourse or otherwise, bending the penile shaft and causing a tear/rupture of the tunica albuginea, and tracking of blood from cavernosal sinuses into the subcutaneous plane. ${ }^{12} \mathrm{~A}$ urethral injury should always be ruled out by asking about any voiding difficulty, history of blood per meatus or haematuria. The

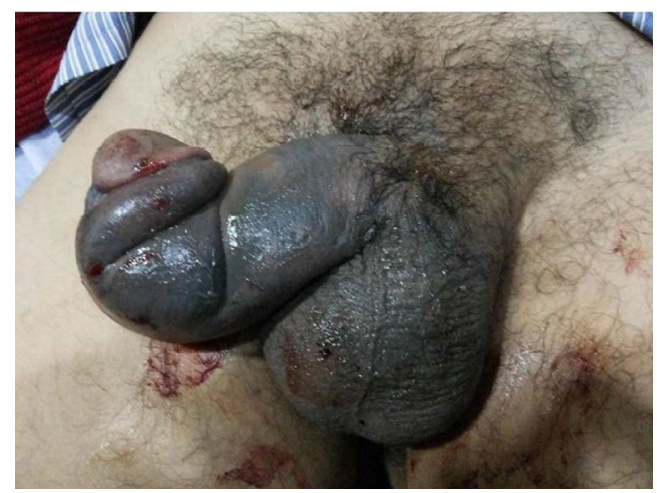

Figure 1 Penis showing dorsal penile angulation with a ventral swelling and ecchymoses of the shaft, called 'eggplant deformity'.

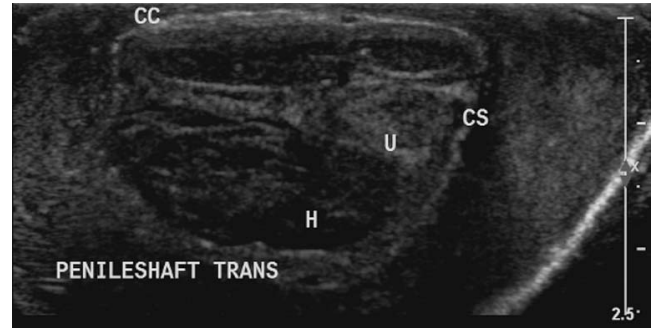

Figure 3 Ultrasound images showing ventral haematoma $(\mathrm{H})$ displacing the corpus spongiosum (CS), and central urethra (U) displaced towards the left with the corpora cavernosa (CC) seen dorsally.

diagnosis is usually clinical and requires prompt surgical intervention. ${ }^{3}$ Sometimes, the presentation may be occult and the patient may present with pain with or without swelling. Point of care ultrasound helps in confirming the diagnosis, aiding the surgeon to locate the site of incision with the least chance of neurovascular injury and skin necrosis. Ruptures of the dorsal penile artery and veins are the most common mimics of penile fracture, and can easily be ruled out by an ultrasound, thus avoiding negative exploration.

\section{Learning points}

- Penile fracture has a classical history and examination findings and should be identified and surgically explored at the earliest to avoid residual penile angulation, painful erections or erectile dysfunction.

- Point of care ultrasound helps confirm findings and rules out other differentials.

- Complete degloving of the penile shaft with its associated complications can be avoided by determining the exact site of tear, by preoperatively using point of care ultrasound.
To cite: Chahal A, Gupta $S$, Das C. BMJ Case Rep Published online: [please include Day Month Year] doi:10.1136/bcr-2016215385

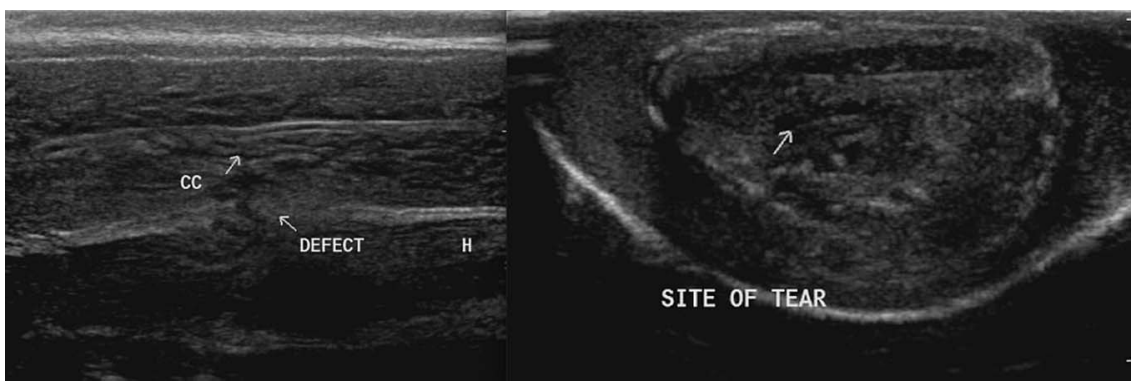

Figure 2 Ultrasound images showing a focal tear (arrow) in the medial wall of right corpora cavernosa (CC) with haematoma $(\mathrm{H})$ tracking ventrally. 
Competing interests None declared.

Patient consent Obtained.

Provenance and peer review Not commissioned; externally peer reviewed.

\section{REFERENCES}

1 Zargooshi J. Penile fracture in Kermanshah, Iran: report of 172 cases. J Urol 2000;164:364-6.

2 Eke N. Fracture of the penis. Br J Surg 2002;89:555-65.

3 Al-Shaiji TF, Amann J, Brock GB. Fractured penis: diagnosis and management. J Sex Med 2009;6:3231-40.

Copyright 2016 BMJ Publishing Group. All rights reserved. For permission to reuse any of this content visit http://group.bmj.com/group/rights-licensing/permissions.

BMJ Case Report Fellows may re-use this article for personal use and teaching without any further permission.

Become a Fellow of BMJ Case Reports today and you can:

- Submit as many cases as you like

- Enjoy fast sympathetic peer review and rapid publication of accepted articles

- Access all the published articles

- Re-use any of the published material for personal use and teaching without further permission

For information on Institutional Fellowships contact consortiasales@bmjgroup.com

Visit casereports.bmj.com for more articles like this and to become a Fellow 